\title{
Effect of chicken manure on chemical properties of a Mollisol and tomato production'
}

\author{
Julia M. O'Hallorans', Miguel A. Muñoz and Octavio Colberg'
}

\begin{abstract}
An experiment was established on a San Antón soil (Cumulic Haplustolls) in southern Puerto Rico to evaluate the effect of chicken manure ( 0 , $5,10$ and $15 \mathrm{t} / \mathrm{ha})$ and nitrogen fertilizer $(0,56,112$ and $168 \mathrm{~kg} / \mathrm{h})$ on some soil chemical properties and tomato production. Chicken manure was broadcast and incorporated into the soil whereas urea, the nitrogen source, was applied by fertigation. A significant lineal effect was observed in exchangeable $\mathrm{Mg}^{2+}$ and $\mathrm{K}^{+}$, electrical conductivity and Olsen available $\mathrm{P}$ with chicken manure applications. In the check treatment (no manure), exchangeable $\mathrm{Mg}^{2+}$ was $2.54 \mathrm{cmol} / \mathrm{kg}$; exchangeable $\mathrm{K}^{+}, 0.99 \mathrm{cmol} / \mathrm{kg}$; electrical conductivity, $0.79 \mathrm{mmhos} / \mathrm{cm}$; and available $P, 52.58 \mathrm{mg} / \mathrm{kg}$. The application of $15 \mathrm{t} / \mathrm{ha}$ of chicken manure increased exchangeable $\mathrm{Mg}^{2+}$ to $2.70 \mathrm{cmol}_{\mathrm{c}} \mathrm{kg}$, exchangeable $\mathrm{K}^{+}$to $1.29 \mathrm{cmol} / \mathrm{kg}$, electrical conductivity to $2.22 \mathrm{mmhos} / \mathrm{cm}$ and available $P$ to $83.98 \mathrm{mg} / \mathrm{kg}$. Soil $\mathrm{pH}$ decreased significantly with the same treatment from 7.50 in the check treatment to 6.98 in the 15 tha chicken manure treatment. Chicken manure increased soil exchangeable $\mathrm{NO}_{3}-$ at a depth of $20 \mathrm{~cm}$, but did not increase exchangeable $\mathrm{NH}_{4}{ }^{+}$. Application of chicken manure did not increase tomato yield significantly; however, it increased significantly the number of large and medium fruits. It is suggested that an exchangeable $\mathrm{NO}_{3}$ - content of about 15 to $20 \mathrm{mg} / \mathrm{kg}$ is adequate for optimum fomato production in a San Antón soil.
\end{abstract}

\section{RESUMEN}

Ffecto de la gallinaza en las propiedades químicas de un Mollisol y en la producción de tomates

Se estableció un experimento en un suelo San Antón (Cumulic Haplustolls) del sur de Puerto Rico para evaluar el efecto de aplicaciones de gallinaza $(0,5,10$ y $15 \mathrm{t} / \mathrm{ha})$ y nitrógeno inorgánico $(0,56,112$ y 168 $\mathrm{kg} / \mathrm{ha}$ ) en algunas propiedades químicas del suelo San Antón y en la producción de tomate. La gallinaza se aplicó a voleo y se incorporó al suelo; la urea, la fuente de nitrógeno inorgánico, se aplicó por fertigación. Se observó un efecto lineal significativo en el contenido de $\mathrm{Mg}^{2+}$ y K intercambiable, conductividad eléctrica y fósforo disponible. En el tratamiento testigo (sin gallinaza) el $\mathbf{M g}^{2+}$ intercambiable era de $\mathbf{2 . 5 4}$ $\mathrm{cmol}_{\mathrm{c}} / \mathrm{kg}$, el K+ intercambiable de $0.99 \mathrm{cmol}_{\mathrm{e}} / \mathrm{kg}$, la conductividad eléctrica de $0.79 \mathrm{mmhos} / \mathrm{cm}$ y el fósforo disponible de $52.58 \mathrm{mg} / \mathrm{kg}$. La aplicación de 15 t/ha de gallinaza aumentó el magnesio intercambiable a $2.70 \mathrm{cmol}_{c}$ '

${ }^{2}$ Manuscript submitted to Editorial Board 2 March 1993.

${ }^{2}$ Research Associate, Agronomy and Soils Department.

${ }^{3}$ Associate Researcher, Agronomy and Soils Department.

${ }^{4}$ Assistant Researcher, Horticulture Department. 
$\mathbf{k g}$, el potasio intercambiable a $1.29 \mathrm{cmol}_{\mathrm{c}} / \mathrm{kg}$, la conductividad eléctrica a $2.22 \mathrm{mmhos} / \mathrm{cm}$ y el fósforo disponible a $83.98 \mathrm{mg} / \mathrm{kg}$. El mismo tratamiento logró disminuir significativamente el $\mathrm{pH}$ del suelo. El $\mathrm{pH}$ disminuyó de 7.50 en el tratamiento control a 6.98 en el tratamiento de 15 t/ha de gallinaza. Las aplicaciones de gallinaza aumentaron el $\mathrm{NO}_{3}-$ intercambiable en los primeros $20 \mathrm{~cm}$ de suelo, sin embargo, no se afectó el $\mathrm{NH}_{4}{ }^{+}$ințercambiable. No se observó efecto significativo de la gallinaza en la producción de tomate, pero si en el número de frutas grandes y medianas. Se sugiere que una concentración de $\mathrm{NO}_{3}{ }^{-}$intercambiable de 15 a $20 \mathrm{mg} / \mathrm{kg}$ sea adecuada para una producción óptima de tomate.

\section{INTRODUCTION}

Because poultry production has become one of Puerto Rico's most important industries, chicken manure disposal is a major problem. Proper management of this material is necessary to prevent damage to the environment. The risks of surface and groundwater contamination are of serious concern. A useful disposal of the manure is its use as a fertilizer. For years chicken manure has been applied to crops in place of nitrogen fertilizers or as a supplemental nutrient source $(1,3,9,16,18)$.

Most of the research with chicken manure has been directed to its use as a nitrogen source with subsequent evaluation of the processes of mineralization and nitrification $(4,5,7,15,16)$. Chicken manure may increase soil organic matter, exchangeable $\mathrm{Mg}^{2+}$ and $\mathrm{K}^{+}$and available $\mathrm{P}$ $(2,9,14,18)$. Shortall and Liebhardt (14) found that chicken manure can also increase soil electrical conductivity to levels that may be detrimental to crops. Liebhardt (9) observed a significant increase in soil electrical conductivity with the application of $224 \mathrm{t}$ of manure per hectare. He associated said effect with an increase in water extractable $\mathrm{K}^{+}$. The same rate of manure also resulted in excessively high levels of available $P$. Bhangoo et al. (1) observed an increase in available $P$ with chicken manure applications at a maximum rate of 9.0 t/ha.

In Puerto Rico some farmers use chicken manure as fertilizer for papaya, plantain, banana, vegetables and pastures (10). Studies have recently been conducted in Puerto Rico to evaluate the effects of chicken manure on crop production. Muñoz and Martínez (11) evaluated time and mode of application of chicken manure for plantain production. An adverse effect was observed during germination with the application of $7.26 \mathrm{~kg}$ manure per plant at planting. However, the same amount of manure split into three or four applications resulted in plant growth and yields similar to those of the check treatment (the recommended inorganic fertilizer treatment). Rafols et al. (13) obtained significant increases in papaya yields attributable to the application of chicken manure. The application of 10 and $15 \mathrm{t} /$ ha resulted in papaya yields of 42.18 and 54.75 t/ha, respectively. The highest yield obtained with inorganic fertilizer (15-15-15) was 42.60 t/ha. The effect of manure applications on chemical properties of Puerto Rican soils needs further evaluation. 
The objective of the study herein reported was to determine effects of chicken manure on some chemical properties of a San Antón soil, a Mollisol from the south coast of Puerto Rico. This is the most important soil series used for vegetable production. A second objective was to evaluate the effect of manure applications on tomato yield and quality. The tomato variety Capitán, which has shown great potential for summer planting, was used as the test crop (19).

\section{MATERIALS AND METHODS}

The experiment was established on a San Antón soil (fine-loamy, mixed, isohyperthermic, Cumulic, Haplustolls) from the south coast of the island. The mean annual temperature for this region is $26^{\circ} \mathrm{C}$ and the mean precipitation is $474 \mathrm{~mm}$. The experimental design was a randomized complete block arranged in a split plot. The main plots were four levels of nitrogen fertilizer $(0,56,112$ and $168 \mathrm{~kg} / \mathrm{ha}$ ); the subplots, four chicken manure levels $(0,5,10$ and $15 \mathrm{t} / \mathrm{ha})$ for a total of 16 treatments. Urea, the nitrogen source used, was applied by fertigation. A low pressure drip irrigation system and silver-coated plastic mulch were used. Chicken manure was broadcasted and incorporated into the soil at a depth of 10 $\mathrm{cm}$. Four soil samplings of the top $20 \mathrm{~cm}$ were performed at 1.5-month intervals to evaluate $\mathrm{pH}$, exchangeable $\mathrm{Ca}^{2+}, \mathrm{Mg}^{2+}$ and $\mathrm{K}^{+}$, electrical conductivity and available P. The soil samples were air-dried and ground to pass a 20 -mesh sieve prior to analysis. Exchangeable basic cations were extracted with $1 \mathrm{~N}$ ammonium acetate buffered at $\mathrm{pH}$ 7. Calcium and magnesium were determined by atomic absorption and potassium by atomic emission (Perkin Elmer 2380). Soil pH was measured on a 2:1 soil:water ratio. Electrical conductivity was determined by extraction of a saturated soil paste (12); available P by extraction with sodium bicarbonate (Olsen method). Available $\mathrm{P}$ was measured colorimetrically by using a Beckman DU 68 Spectrophotometer. Two months after planting, soil samples were collected at two depths $(0$ to $20 \mathrm{~cm}$ and 20 to $40 \mathrm{~cm}$ ) to determine exchangeable $\mathrm{NH}_{4}+\mathrm{N}$ and $\mathrm{NO}_{3}-\mathrm{N}$. Ammonium and nitrate were extracted with $2 \mathrm{~N} \mathrm{KCl}$ and analyzed by steam distillation (12).

Table 1 presents chemical analysis of the manure. Available nutrients were determined by following a methodology similar to that for the soil samples. Total nutrients were determined by a digestion with sulfuric acid and hydrogen peroxide. Nitrogen and phosphorus were analyzed colorimetrically, calcium and magnesium by atomic absorption and potassium by atomic emission.

Tomatoes were planted 1 week after the application of chicken manure. Each subplot consisted of three beds $4.57 \mathrm{~m}$ long and $1.83 \mathrm{~m}$ wide, with a row of 11 tomato plants (variety, Capitán) in each bed. Harvest began 2.5 months after planting. Tomatoes were harvested in 11 pickings 
TABLE 1.-Chemical anlysis of chicken manure

Available nutrient $(\mathrm{mg} / \mathrm{kg})$

Phosphorus 1799
Potassium 16100

Total nutrients(\%)

Nitrogen

3.35
Phosphorus

2.24
Calcium
4343

Potassium
2.09 $\underset{4895}{\text { Magnesium }}$

$\mathrm{pH}$

7.34

performed at intervals of approximately 7 days. Tomato fruits were classified by diameter: large $>72.60 \mathrm{~mm}$; medium $<72.60>64.10$; small $<$ $64.10>55.66$. Number and weight of fruits were noted for each classification.

\section{RESULTS AND DISCUSSION}

Soil $\mathrm{pH}$ decreased linearly with chicken manure applications (fig. 1). Average soil pH for the check treatment was 7.50, whereas for the 5, 10 and $15 \mathrm{t} / \mathrm{ha}$ treatments $\mathrm{pH}$ was $7.31,7.16$ and 6.98 , respectively. Nitrifi-

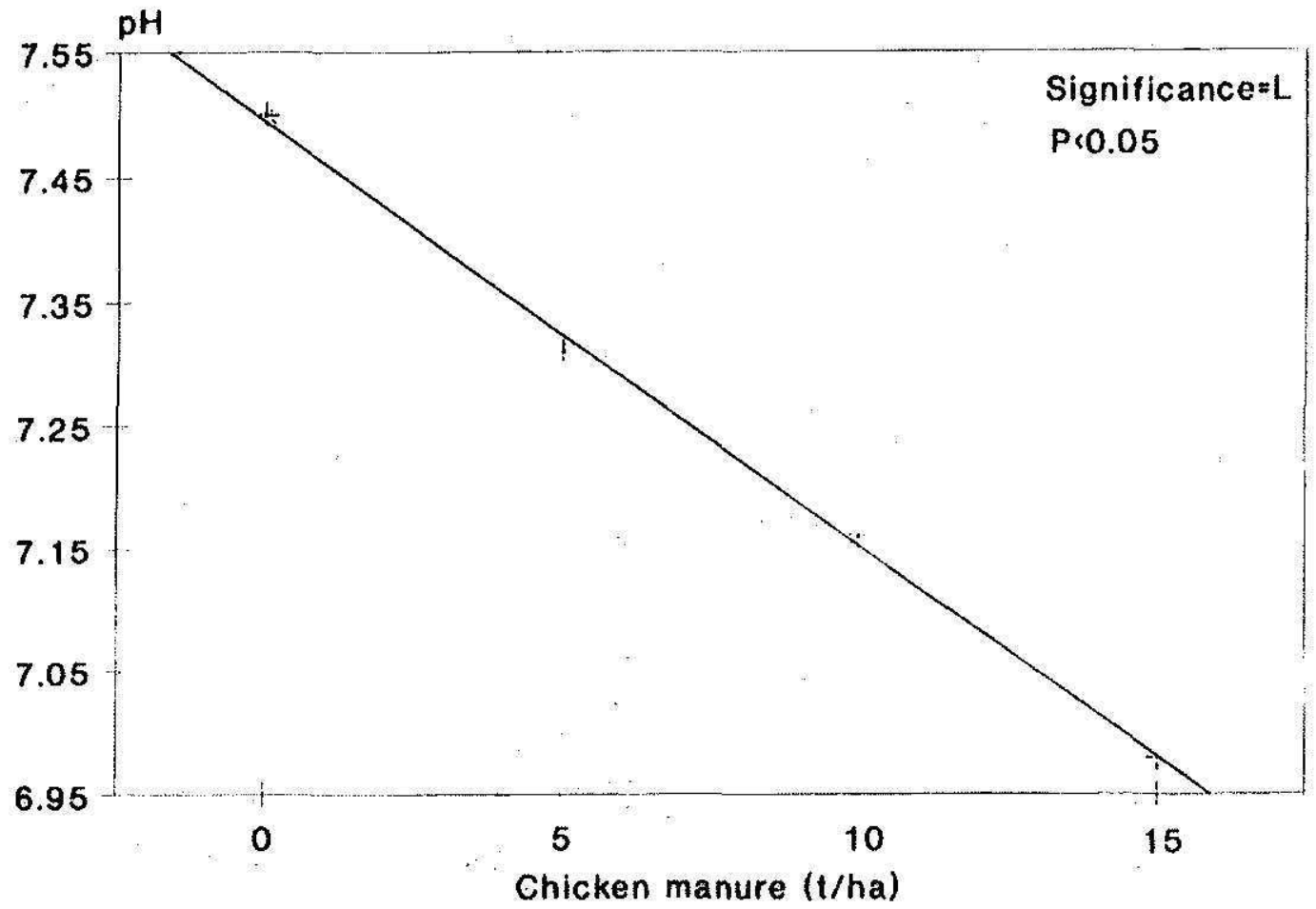

FIG. 1.-Chicken manure effect on soil pH 
J. Agric. Univ. P.R. vol. 77, No. 3-4, JuLY/OCTOBER, 1993185

cation might be the major cause of the reduction in soil $\mathrm{pH}$. During the transformation of $\mathrm{NH}_{4}{ }^{+}$to $\mathrm{NO}_{3}$, hydrogen ions are generated, causing acidification (17). Another factor influencing the $\mathrm{pH}$ is soil electrical conductivity. An increase in electrical conductivity also reflects an increase in the ionic strength of the soil solution, which favors the dissociation of $\mathrm{H}^{+}$ions from the surface charges (20). Figure 2 shows such an effect where soil $\mathrm{pH}$ decreases linearly as electrical conductivity increases.

Manure applications had a significant lineal effect on electrical conductivity (fig. 3). Before manure applications, electrical conductivity values fluctuated between 0.57 and $0.60 \mathrm{mmhos} / \mathrm{cm}$. Applcations of $0,5,10$ and $15 \mathrm{t} / \mathrm{ha}$ of manure resulted in conductivity values of $0.49,1.20,1.83$ and $2.22 \mathrm{mmhos} / \mathrm{cm}$, respectively. Several ions can contribute to increasing the electrical conductivity; however, the increase in exchangeable and water soluble $\mathrm{K}^{+}$has been strongly correlated with electrical conductivity in manure-amended soils $(9,14)$. Our results indicated a linear increase in exchangeable $\mathrm{K}^{+}$with manure applications (table 2). Drip irrigation and rainfall influence the movement of salts into the soil profile, and thus the conductivity. For example, at 1.5 months after manure application (MAA) the $15 \mathrm{t} / \mathrm{ha}$ treatment showed a conductivity value of $2.81 \mathrm{mmhos} /$ $\mathrm{cm}$ (fig. 4). On the second sampling (3.0 MAA), the conductivity was 2.43 $\mathrm{mmhos} / \mathrm{cm}$; on the third sampling (4.5 MAA) it was $1.42 \mathrm{mmhos} / \mathrm{cm}$.

Exchangeable $\mathrm{Mg}^{2+}$ and $\mathrm{K}^{+}$increased significantly with manure applications; however, exchangeable $\mathrm{Ca}^{2+}$ decreased (table 2). This effect can

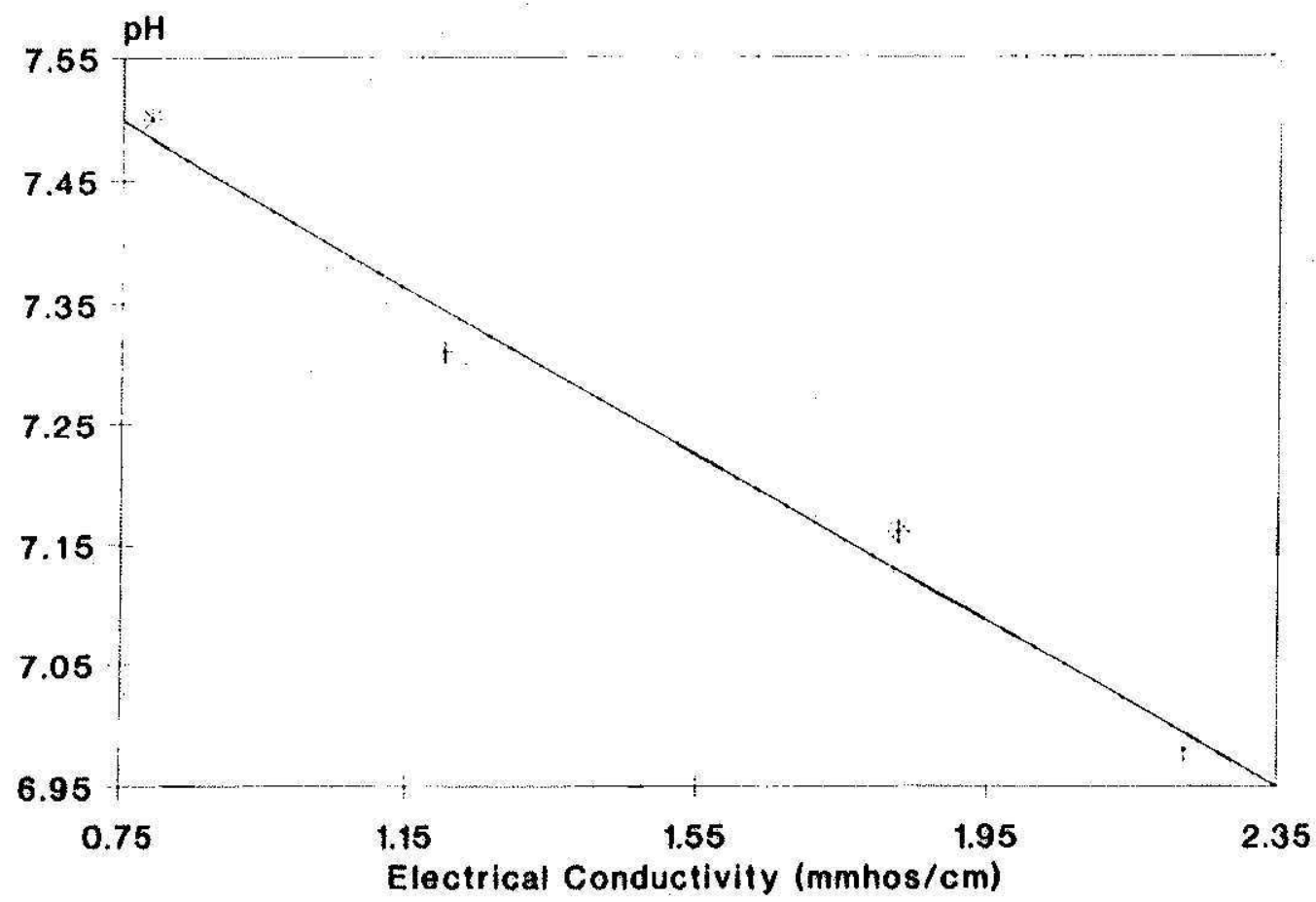

FIG. 2.-Relationship between $\mathrm{pH}$ and soil electrical conductivity 


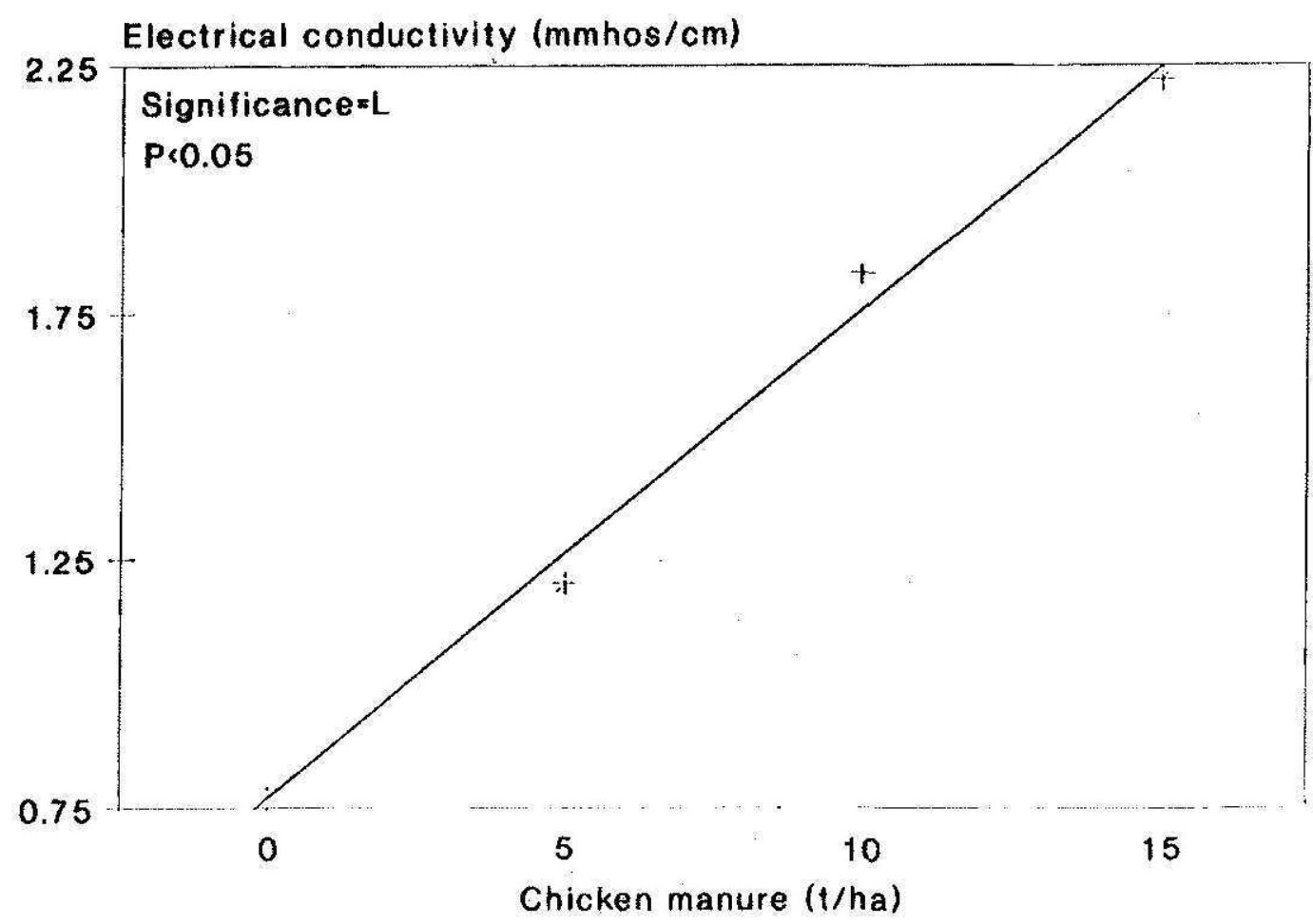

FIG. 3.-Chicken manure effect on soil electrical conductivity

be related to the reduction in $\mathrm{pH}$ and the increase in electrical conductivity. Calcium ions are replaced in the exchange sites of the soil by $\mathrm{H}^{+}$ions resulting from nitrification, and by $\mathrm{Mg}^{2+}$ and $\mathrm{K}^{+}$ions present in the manure. The $\mathrm{Ca}^{2+}$ in the manure is apparently less soluble than the $\mathbf{M g}^{2+}$ and $\mathrm{K}^{+}$. The chemical analysis of the manure (table 1 ) indicated that although the $\mathrm{Ca}^{2+}$ content in the manure was larger than the $\mathrm{Mg}^{2+}$ and $\mathrm{K}^{+}$, the fraction considered available (ammonium acetate-extractable) was lower. The sum of cations remained constant. This finding indicates that the manure did not contribute significantly to the cation exchange capacity (CEC) of the soil (table 2).

TABLE 2.-Effect of chicken manure on soil exchangeable $\mathrm{Ca}^{\alpha+}, \mathrm{Mg}^{\alpha+}$ and $\mathrm{K}^{+}$and the sum of cations

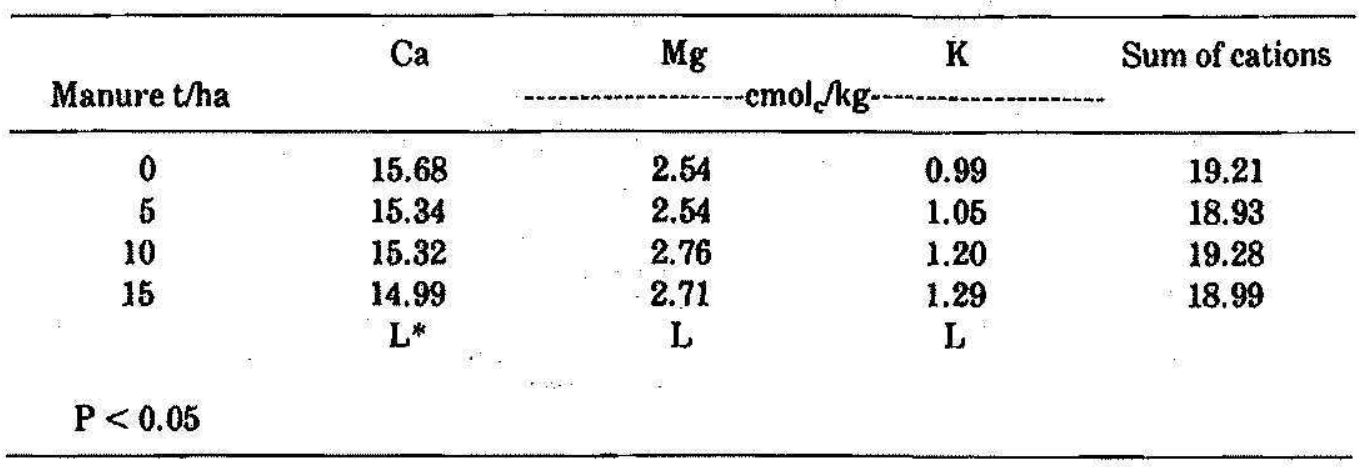

$\left({ }^{*} \mathrm{~L}=\right.$ Lineal effect $)$ 
J. Agric. Univ. P.R. vol. 77, NO. 3-4, JULY/OCTOBER, 1993187

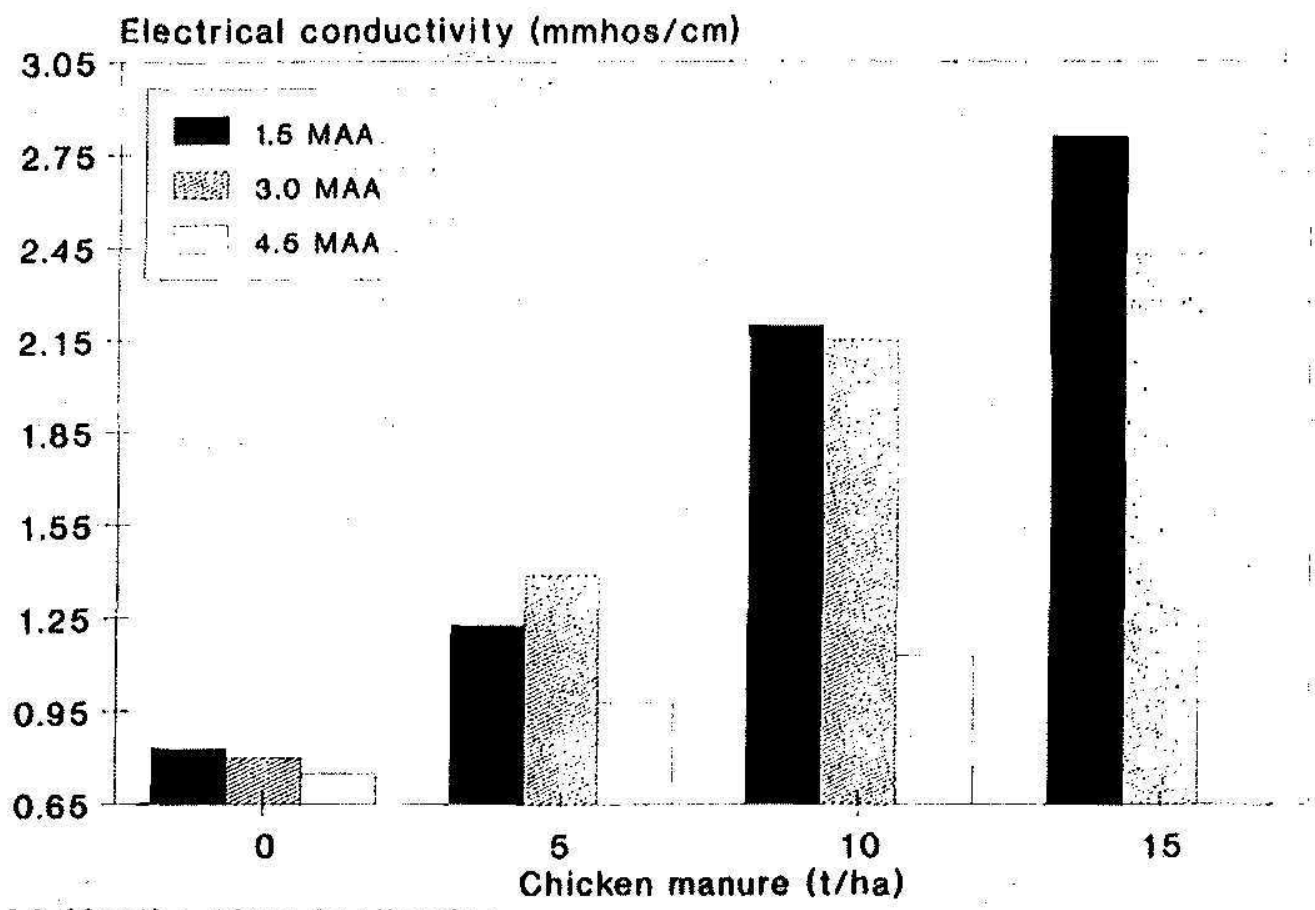

MAA-Months After Application

FIc. 4. Effect of manure applications and time of sampling on soil electrical conductivity

Soil available-P increased significantly with manure applications (fig. '5). This increase is partially the result of the phosphorus present in the manure (table 1). Also, the $\mathrm{pH}$ reduction may have enhanced the solubil-

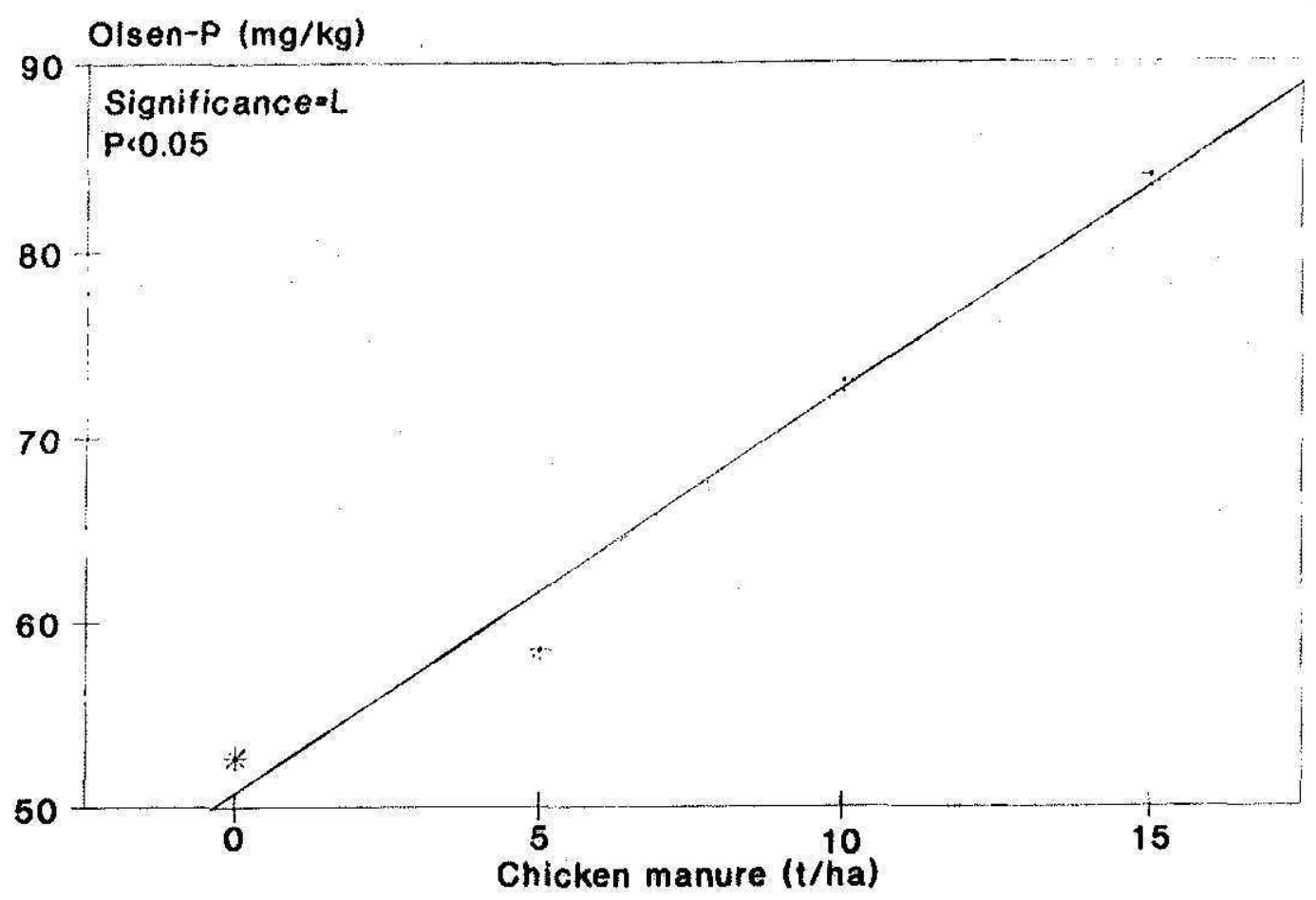

Fig. 5. Chicken manure effect on soil available $P$ 
ity of $\mathrm{Ca}$ and $\mathrm{Mg}$ phosphates present in the soil. Available $\mathrm{P}$ concentration decreased with time of sampling in the 5,10 and $15 \mathrm{t} / \mathrm{ha}$ manure treatments. The first sampling (1.5 MAA) showed the highest concentration of available P. However, in the 4.5 MAA sampling an increase was observed over the 3.0 MAA sampling. This effect may be attributed to the application of phosphoric acid, used to clean the irrigation lines. After 6.0 months the available $P$ levels were significantly lower than at 1.5 months (fig. 6). The decrease in available $P$ observed after 6 months can be attributed to plant uptake and microorganism assimilation.

A significant lineal effect of manure applications was observed in exchangeable $\mathrm{NO}_{3}{ }^{-}$at a depth of $20 \mathrm{~cm}$ (fig. 7). The check treatment showed a value of $14.57 \mathrm{mg} / \mathrm{kg}$ and the $15 \mathrm{t} / \mathrm{ha}$ treatment $24.1 \mathrm{mg} / \mathrm{kg}$. A significant effect was also observed in $\mathrm{NO}_{3}{ }^{-}$content at a depth of 20 - to 40 -cm depth (fig. 8). The check treatment presented a value of $3.5 \mathrm{mg} / \mathrm{kg}$ and the 15 t/ha $11.0 \mathrm{mg} / \mathrm{kg}$. The $\mathrm{NO}_{3}{ }^{-}$present in the soil at a depth of 20 to $40 \mathrm{~cm}$ may be of limited use for tomato plants. Tomato roots develop in the first $20 \mathrm{~cm}$ of soil, especially when a plastic mulch is used (8). Therefore, exchangeable $\mathrm{NO}_{3}^{-}$below that depth may be lost by leaching. Ammonium nitrogen did not vary significantly with chicken manure or nitrogen fertilizer applications. The lack of significant differences may be due to

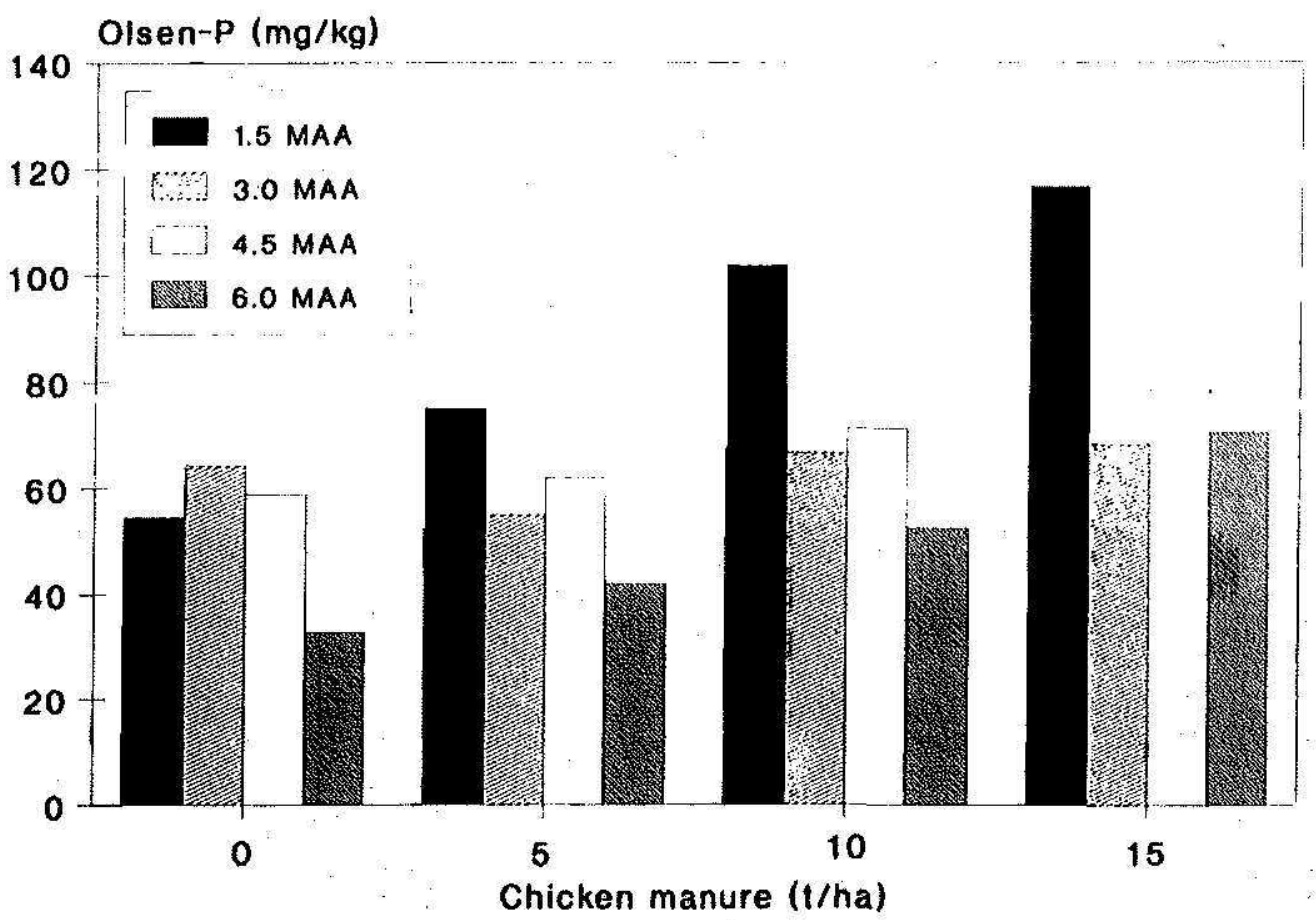

MAA=Months After Application

Fic. 6.-Effect of manure application and time of sampling on soil available $P$ 
J. Agric. Univ. P.R. vol. 77, NO. 3-4, JULY/OCTOBER, 1993189

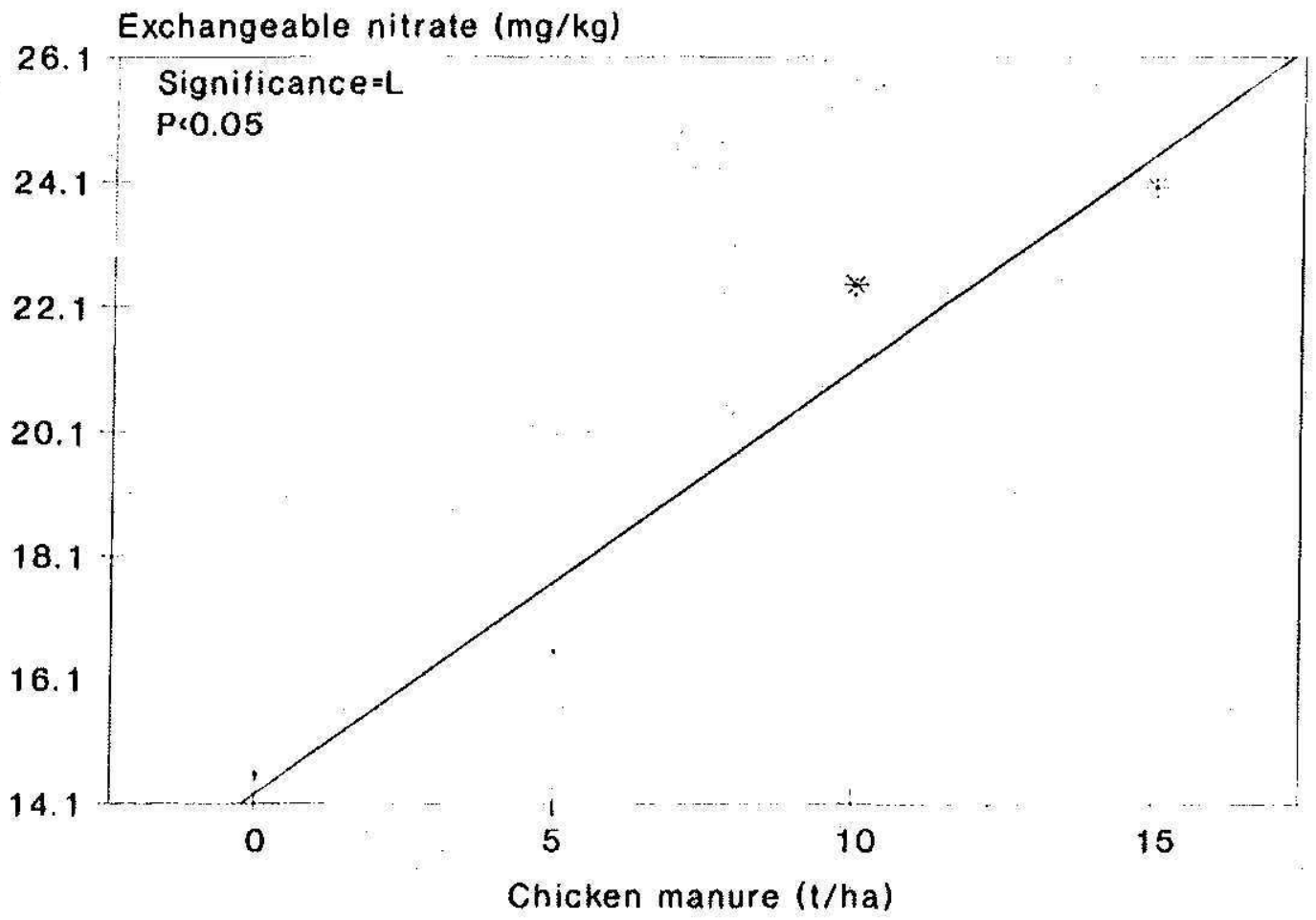

Fig. 7.-Chicken manure effect on soil exchangeable $\mathrm{NO}_{3}-(0$ to $20 \mathrm{~cm})$

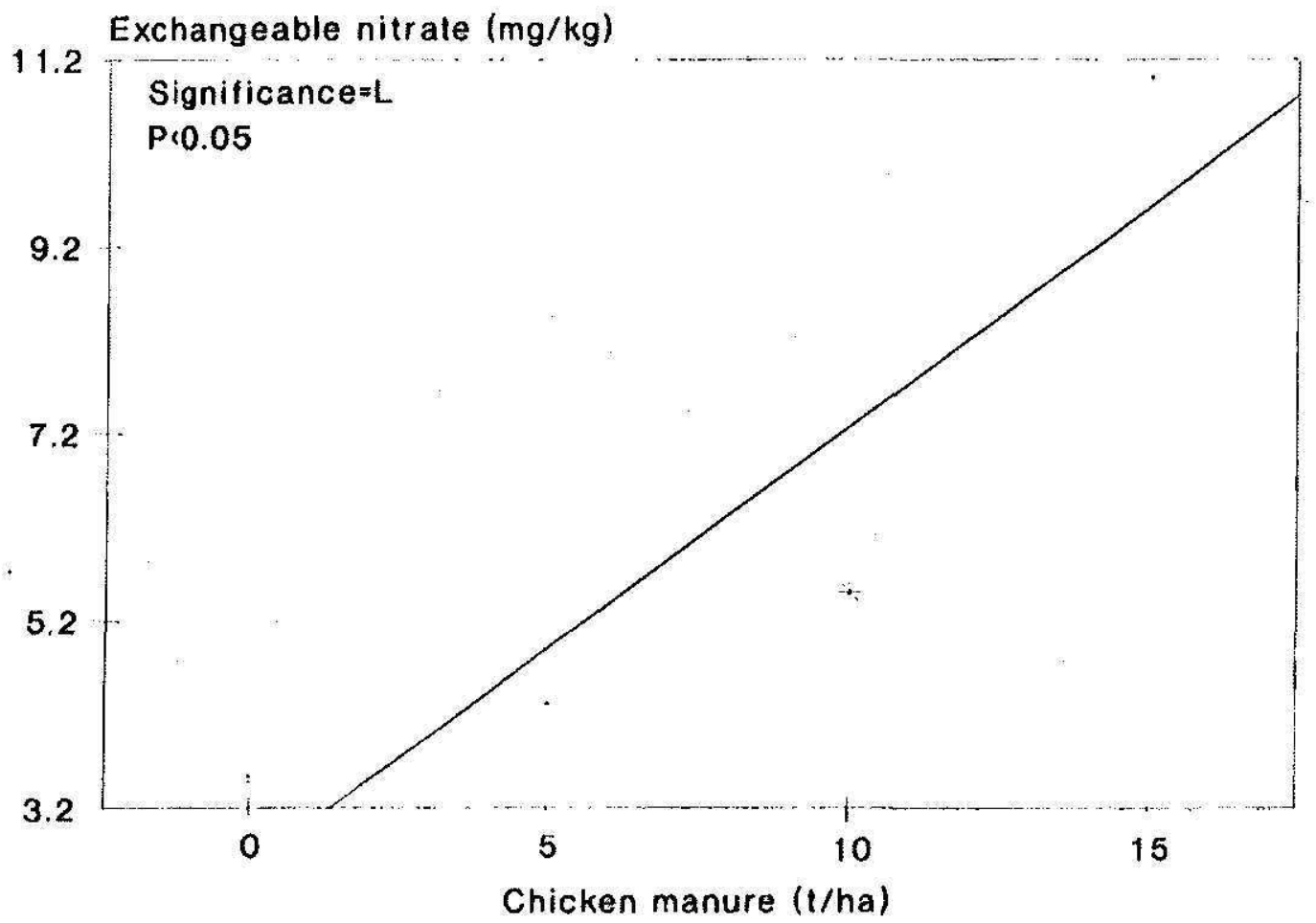

Fig. 8. - Chicken manure effect on soil exchangeable $\mathrm{NO}_{3}-(20$ to $40 \mathrm{~cm}$ 
nitrification processes and nitrogen volatilization. No significant differences were observed in $\mathrm{NO}_{3}{ }^{-} \mathrm{N}$ content with nitrogen fertilizer applications.

No significant differences were observed in tomato production (table 3). However, manure treatments did increase significantly the number of large and medium fruits (table 4). The 15 t/ha manure treatment resulted in an increment of 10,615 large fruits and 30,807 medium fruits when compared to the check treatment. The high fertility of San Antón soil is determinant in the absence of significant differences. In our study exchangeable $\mathrm{NO}_{3}{ }^{-}$levels in the range of 15 to $25 \mathrm{mg} / \mathrm{kg}$ were associated with optimum tomato yields. Recent studies with corn $(2,6)$, a more demanding crop in terms of nitrogen requirement, have shown that exchangeable $\mathrm{NO}_{3}{ }^{-} \mathrm{N}$ levels of $25 \mathrm{mg} / \mathrm{kg}$ were associated with optimum yields.

Chicken manure has a potential as an organic fertilizer because of its nutrient content. Its application to the soil in adequate amounts increases soil fertility and thus increases crop production. However, a farmer using chicken manure should be aware of the environmental problems that excessive accumulation and poor handling can cause. An excess of chicken manure applied to the crop can result in nutrient imbalance, salinity problems and nitrate losses by runoff and leaching.

TABLE 3.-Effect of chicken manure and nitrogen fertilizer on tomato (tha) production

\begin{tabular}{cccccc}
\hline & \multicolumn{5}{c}{ Nitrogen (kg/ha) } \\
\cline { 2 - 6 } Manure t/ha & 0 & 56 & 112 & 168 & X \\
\hline 0 & 79.9 & 87.0 & 89.4 & 84.8 & 85.2 \\
5 & 91.2 & 91.4 & 95.8 & 89.2 & 91.9 \\
10 & 91.1 & 91.7 & 100.2 & 84.7 & 91.9 \\
15 & 98.0 & 84.6 & 96.9 & 88.4 & 90.7 \\
X & & & & & \\
\hline
\end{tabular}

TABLE 4.-Effect of chicken manure on tomalo fruit number and size (fruits/ha).

\begin{tabular}{cccc}
\hline Manure t/ha & Large & Medium & Small \\
\hline 0 & 35,863 & 195,980 & 150,336 \\
5 & 44,979 & 217,233 & 163,703 \\
10 & 45,875 & 224,447 & 166,915 \\
15 & 46,028 & 226,787 & 157,053 \\
& $\mathrm{~L}^{*}$ & $\mathrm{~L}$ & $\mathrm{~L}$ \\
\hline
\end{tabular}

$\left({ }^{*} \mathrm{~L}=\right.$ Lineal effect; $\mathrm{NS}=$ no significance $)$. 


\section{LITERATURE CITED}

1. Binford, G. D., A. M. Blackmer and M. E. Cerrato, 1992. Relationships between corn yields and nitrate in late spring. Agron. J. 84: 53-59.

2. Bhangoo, M. S., K. S. Day, V. R. Sudanagunta and V. E. Petrucci, 1988. Application of poultry manure influences Thompson seedless grape production and soil properties. Hort. Sci. 23: 1010-1012.

3. Carreker, R., S. R. Wilkinson, J. E. Box, R. N. Dawson, E. R. Beaty, H. D. Morris and J. B. Jones, 1973. Using poultry litter, irrigation, and tall fescue for no-till corn production. J. Environ. Qual. 2: 497-500.

4. Castellanos, J. Z. and P. F. Pratt, 1981. Mineralization of nitrogen-correlation with laboratory indexes. J. Soil Sci. Soc. Am. 45: 354-357.

5. Chae, Y. M. and M. A. Tabatabai, 1986. Mineralization of nitrogen in soil amended with organic wastes. J. Environ. Qual. 15: 198-198.

6. Fox, R. H., G. W. Roth, K. V. Iversen and W. P. Piekielek, 1989. Soil and tissue nitrate test compared for predicting soil nitrogen availability to corn. Agro. J. 81: 971-974.

7. Hadas, A. A. R, 19-74. Comparative changes in soil physical properties induced by admixtures of manures from various domestic animals. Soil Science 118 53-59.

8. Knavel, D. E. and H. C. Morth, 1967. Distribution of roots of four different vegetables under paper and polyethylene mulches. Am. Soc. Hort. Sci. Proc. 91: 589-597.

9. Liebhardt, W. C., 1976. Soil characteristics and corn yield as affected by previous applications of poultry manure. J. Eviron. Qual. 5 459-462.

10. Muñoz, M. A., 1992. Conversión y uso de gallinaza en Puerto Rico. Memorias de Foro Téenico. Estación Experimental Agricola. 23 de febrero 1990, pp. 15-25.

11. — and G. Martinez, 1991. Chicken manure: An organic fertilizer for plantains (Musa acuminata $\times$ M. balbisiana AAB). Proc. Caribbean Food Crops Society 27: 225-233, Roseau, Dominica.

12. Page, A. L., R. A. Miller and D. R. Keeney, 1982. Methods of Soil Analysis, Part 2: Chemical and Mineralogical Properties. $2^{\text {nd }}$ Ed. Am. Soc. Agron. Madison, Wiscon$\sin$.

13. Rafols, N., M. A. Muñoz, R. Del Valle and L. Peña, 1991. Effect of chicken manure application on yield and yield components of papaya (Carica papaya, L.). Am. Soc. Agron. Abstract p298.

14. Shortall, J. C. and W. C. Liebhardt, 1975. Yield and growth of corn as affected by poultry manure. J. Environ. Qual. 4: 186-191.

15. Sims, J. T., 1986. Nitrogen transformations in a poultry manure amended soil:Temperature and moisture effects. J. Environ. Qual. 15: 59-63.

16. - 1987. Agronomic evaluation of poultry manure as a nitrogen source for conventional and no-tillage corn. Agron. J. 79: 563-570.

17. Tisdale, S. L. and W. L. Nelson, 1985. Soil Fertility and Fertilizers. $4^{\text {th }}$. Ed. McMillan Publishing Co. Inc. New York, New York.

18. Weil, R. R., W. Kroontge and G. D. Jones, 1979. Inorganic nitrogen and soluble salts in a Davidson clay loam used for poultry manure disposal. J. Environ. Qual. 8: 86-91.

19. Wessel-Beaver, L., G. Fornaris, A. Armstrong, E. Caraballo and L. Velázquez, 1990. Extending the tomato season in Puerto Rico: Problems of summer production Proc. Caribbean Food Crops Society 26: 668-573, Mayaguez, Puerto Rico.

20. Westerman, R. L., 1990. Soil Testing and Plant Analysis. $3^{\text {rd }}$ Ed. Soil Science Sociely America, Inc. Madison, WN. 784 pp. 